\title{
Agroforestry systems practiced in Dhamtari district of Chhattisgarh, India
}

\author{
Pratap Toppo, Abhishek Raj and M. K. Jhariya ${ }^{1^{*}}$ \\ Department of Forestry, College of Agriculture, Indira Gandhi Krishi Vishwavidyalaya, Raipur- 492012 (C.G.), \\ INDIA \\ ${ }^{1}$ Department of Farm Forestry, Sarguja University, Ambikapur-497001 (C.G.), INDIA \\ "Corresponding author. E-mail: manu9589@gmail.com
}

Received: December 21, 2016; Revised received: July 21, 2016 Accepted: October 20, 2016

\begin{abstract}
Chhattisgarh state has very diverse forest ecosystem and long history of traditional agroforestry. An agroforestry practice is location specific and depends on nature of agro-climatic zone. In Chhattisgarh, farmers are doing this farming practices based on fulfilling their diverse need and improvement of socioeconomic condition but still data is insufficient to explore more agroforestry practices in the state. In this context, assessment of different agroforestry models gives not only sufficient data but also open a door for conservation of biological diversity.. Different models like's Boundary plantations, Agri-silviculture system, Horti-silvicuture, Silvi-pasture, Kitchen garden and Block plantation are used by farmers in Dhamtari. All models are dependent on location characteristic, land use type, soil type, climate and market requirement. This paper highlights the different models of Agroforestry, specific model for the specific sites, lacuna in models faced by farmers and role of agroforestry models in socioeconomic upliftment.
\end{abstract}

Keywords: Agroforestry system, Farming practices, Model, Land use

\section{INTRODUCTION}

The central India forms one of the major ecosystems of the Indian subcontinent (Toppo et al., 2014; Raj et al., 2016a; Toppo et al., 2016). From ancient time, India has been practicing a tradition farming system of agroforestry comprises cultivation of a variety of woody perennials with their associated crop and livestock, depending upon the agro-climatic conditions and local needs. Agroforestry may be defined as an efficient and integrated land use management system by raising of certain agricultural crops, forest tree species and or animals simultaneously or sequentially on the same unit of land with appropriate management practices which result in overall increase in the production under a particular set of climatic and edaphic conditions and socioeconomic status of local people (King, 1969). It is the new name for an ancient land use practice and just a compromise between agriculture and forestry to maintain the need of forest cover upto $33 \%$ as per given national forest policy (Raj et al., 2014a; Jhariya et al., 2015; Raj et al., 2016b; Singh and Jhariya, 2016). Tree species like Dalbergia sissoo, Azadirachta indica, Acacia nilotica, Grewia optiva, Morus alba, Ficus spp., etc. are grown on the borders of fields for meeting demand of timber, fodder, fuel etc is common practices throughout the country (Singh, 1993). It can improve the livelihoods of smallholder farmers as by providing fruit and nuts, fuel wood, timber, medicine, fodder for livestock, green fertilizers, additional / di- versified income (WAC, 2010).

Chhattisgarh state is rich in forest and has a vast variety of minor forest products to favourable agroclimatic conditions resulting in good forest area, i.e. $43.6 \%$ of the total. Rice is the major crop $(27.24 \%$ of geographical area of Chhattisgarh) cultivated in different part of Chhattisgarh state. A. nilotica, Butea monosperma, Gmelina arborea, A. indica, D. sissoo etc are practiced under agroforestry system. Similarly, Jhariya et al. (2013) has concluded a large scale plantation of $A$. indica trees help to combat desertification, deforestation, soil erosion and to reduce excessive global temperature. Although, neem is natural source of insecticides, pesticides and agrochemicals and also used as bio-control agent to control many plant disease (Raj, 2014). Moreover, tree component of agroforestry produce tangible products in sustainable way (Raj and Jhariya, 2016). Exploiting Babul tree for gum tapping will help farmers to strengthen their socioeconomic conditions as well as to help conserve environment and biodiversity too (Raj, 2015a) and gum production was also depending upon the girth of tree, relative humidity and temperature, applied number of injury and chemical concentration (Das et al., 2014; Raj, 2015b). Biodiversity balance the food chain, food web, $\mathrm{CO}_{2}$ sequestration, nutrient cycling and livelihood of human being (Jhariya and Raj, 2014). Agroforestry practices are however, very location specific and information on these is very scanty, therefore, need to explore more to more different pattern of agroforestry practices in 
Chhattisgarh. This will start from documentation and assessment of different practices in India and leads to conservation of this biological diversity.

\section{MATERIALS AND METHODS}

Study area: Chhattisgarh state has three distinguished agro-climatic zones viz; northern hill, central plains and southern Baster plateau region. The work was conducted in the year 2014 in Dhamtari district of Chhattisgarh, which lies in southern region of Chhattisgarh and situated between $20^{\circ} 42^{\prime} \mathrm{N}$ latitude and $81^{\circ} 33^{\prime}$ longitude. It has an average elevation of $305 \mathrm{~m}$ above sea level. The climate of the area is tropical and annual rainfall is $1372.5 \mathrm{~mm}$. The total area of forest is 8760 ha which is $2.14 \%$ of total geographical area of Dhamtari (408190 ha).

Traditional agroforestry practices adopted by the farmers were identified through the preliminary surveys of the area and in consultation with the local residents. The study was carried out in Dhamtari district comprises 4 blocks. For study purpose three villages were selected in each block of district purposively because it have good irrigation facility, which is necessary for supporting Agroforestry system. Thus, in all 12 villages were selected and within each village again $10 \%$ sampling was done for collecting information from the households and the information was collected by questionnaire method, informal interviews, participatory rural appraisal, transact walk along with the farmers and personal observations. Key informants were identified after priliminary discussion with people. The selected informants were interviewed and the conversation followed was documented so as to record the existing traditional agroforestry systems and indigenous practices and results were documented along with opinion and expression of the respondents. Questionnaire for design and diagnostic survey was prepared as per the guidelines laid down by ICRAF for ICARF's global inventory of agroforestry systems (Nair, 1989).

\section{RESULTS AND DISCUSSION}

Different types of agroforestry practices/models were seen in the village of Dhamtari. They practiced and followed agroforestry in order to meet his diverse needs. Systems identified (Table 1) and tree preference for various uses (Table 2) is discussed as follows:

Boundary plantations: Traditionally, farmers of Dhamatari districts are used Terminalia arjuna, A. nilotica, Terminalia tomentosa, Zizyphus maurtiana, B. monosperma, Albizzia lebbeck on the boundary of paddy fields. From above mention species Terminalia species dominantly found naturally on bunds followed by $A$. nilotica, A. lebbeck and B. monosperma, Whereas Tectona grandis and $G$. arborea were managed as bund plantation. Generally plantation of $T$. grandis and $G$. arborea are maintained at $2 \times 2 \mathrm{~m}$ spacing on bund besides farmers used to grow some commercial species such as $D$. sissoo, A. lebbeck including fruits species comprises Z. mauritiana and Syzigium cumini at $4 \times 4$ and $5 \times 5$. The size of bunds ranges from 0.5 to $2.0 \mathrm{~m}$. The soil characteristics is black cotton. Generally, farmers used to cultivate paddy in kharif season but in irrigated land farmers cultivate wheat and gram in rabi season. This system is adopted by small as well as big farmers. But recently, farmers are using teak on bund based agroforestry. Sometimes, farmers feared to cultivate tree crop on bund because of shading effects on associated agricultural crop and this negative effects can be minimized through best management practices comprises tending operation, silvicultural practices, prescribe suitable spacing. Also, ecological sustainability and success of any agroforestry system depends on the inter-play and complementarily between negative \& positive interactions. It can yield positive results only if positive interactions outweigh the negative interactions (Singh et al., 2013).

Agri-silviculture system: Farmers used trees like $A$. nilotica and $B$. monosperma within the agricultural field $w$ hereas in upland condition, A. nilotica and $B$. monosperm, Madhuca indica, Terminalia chebula, Terminalia belerica and S. cumini species are prefered. People raise forest tree species around their farms, which serve as boundaries as well as provide much needed fuel and fodder. Sometimes tree may be found scattered inside the farm area also. Farmers are adopted this model for fulfilling their basic needs as timber, fuelwood, fodder, agricultural implements, non -timber forest products. Majority of growers are used to adopt timber tree species as compared to horticultural tree species under this model. More than $90 \%$ of the study sites, tree species comprises $M$. indica, Anogeissus latifolia, T. tomentosa, Diospyros melonoxylon, Schleichera oleosa, T. grandis, G. arborea, T. arjuna and $A$. nilotica etc. The farmers in the study area generally retain those species which are regenerated naturally on the field, while artifically they go for high value species like $T$. grandis, G. arborea, D. sissoo etc. . They collect the fruit and seed from $T$. chebula, T. belerica and S. cumini and sell in near local market. Somewhat it helps for uplifting their socioeconomic condition and works as employment generating source.

Horti-silvicuture: Under this model, majority of farmers used Mangifera indica based orchard, besides these other species prefereed by farmers were, Emblica officinalis, Psidium guajava, Punica granautum, Aegle marmelos, Z. mauritiana based hort-silviculture in small scale. The main purpose of the system is the production of fruits for marketing to raise their income leads to socioeconomic upliftment. However, this system is not specifically managed. Farmers retain $M$. indica, Annona squamosa and Z. mauritiana substantially on field while $S$. cumini, S. oleosa and A. marmelos found in small scale. Similarly they prefered woody species as, T. grandis, G. arborea, A. lebbeck, 
T. arjuna and $A$. nilotica on field. The main constraint of horti-silviculture model are managerial aspects and lack of availability of suitable fruits species which raised in short duration that gives yield in early soon as possible. Generally, farmers are facing disease and pest attack on fruits crops (fruits flies) that leads to low production and not economically viable.

Silvi-pasture model: This system is practiced on degraded and wasteland for restoration/reclamation purpose. Tree species are generally grown in scattered manner within grasses field. This system is used for protein bank i.e. farmers collect protein rich leaves for their cattle's for feeding pupose. Pasture grasses grown include Dicanthium annulatum and Cynodon dactylon with tree species comprises $A$. lebbeck, A. nilotica, $F$. spp., Leucaena leucocephala M. indica, Z. maurtiana, Pithecellobium dulce, Tamarindus indica, T. tomentosa and A. latifolia etc.

Kitchen garden: This system is practiced throughout the district and is generally common among those farmers who have a land holding of about 50-300 square meters located just around their residence. On the piece of land people raise fruit trees and vegetables of all kinds round the year. Trees raised on the land are Eucalyptus species and G. arborea with fruit trees are $P$. granatum, Annona reticulate, $P$. guajava, Musa paradisica, Carica papaya, Citrus species, E. officinalis and $A$. marmelos. Vegetables are grown in the inter spaces of fruit trees and may include cabbage, turnip, radish, carrot, onion, peas, spinach, colocasia, cucurbits etc. Medicinally important species like aloe vera, buch, tulsi, satavar, mint are used to raise in Kitchen garden. The problem with kitchen garden is that it is established on a small piece of land and sometimes people have to hire labour for the purpose of cultivation which they cannot afford as they are generally poor farmers.

Block plantation: Trees like $T$. grandis, D. sissoo, $G$. arborea, E. species and L. leucocephala are major species found under block plantation. Traditionally eucalyptus is used for block plantation but recently farmers grown $T$. grandis and G. arborea in small patch.

After extensive survey, we have collected a lots of information regarding different models that are practiced by rural farmers/people for meeting some of their diverse needs i.e. food, fodder, fuelwood, and timber and also documenting flora (woody tree, shrubs and herbaceous crop) species for further study in conservation aspects. Therefore, documentation is the first step ahead before the next step of conservation of these biological resources (Raj and Toppo, 2014; Painkra et al., 2015). But the landholding size are low i.e. not sufficient to get all their consumption needs from the farm in adequate quantities. That's why sometimes; farmers used cow dung as energy resources for fuel consumption. It is one of the renewable and sustainable energy resources through dung cakes or biogas which replace the dependence upon charcoal, fuel wood, firewood and fossil fuel etc (Raj et al., 2014b). These observations have also been reported by Mughal et al. (2000) and Mughal and Bhattacharya (2002). Also, the production per unit area of food grains except paddy and oil seeds is also less, besides people do not practice agroforestry wholeheartedly on all the available land area.

Table 1. Different agroforestry systems or models used in Dhamtari district.

\begin{tabular}{|c|c|c|c|c|}
\hline \multirow[t]{2}{*}{ System } & \multirow[t]{2}{*}{ Tree component } & \multirow[t]{2}{*}{ Fruit tree component } & \multicolumn{2}{|c|}{ Agricultural crop component } \\
\hline & & & Rabi & Kharif \\
\hline Boundary plantations & $\begin{array}{l}\text { Terminalia arjuna, Acacia } \\
\text { nilotica, Terminalia tomentosa, } \\
\text { Zizyphus maurtiana, Butea } \\
\text { monosperma, Albizzia lebbeck }\end{array}$ & - & $\begin{array}{l}\text { Wheat and } \\
\text { Gram }\end{array}$ & Paddy \\
\hline $\begin{array}{l}\text { Agri-silviculture } \\
\text { system }\end{array}$ & $\begin{array}{l}\text { Acacia nilotica, Butea mono- } \\
\text { sperm, Madhuca indica, Termi- } \\
\text { nalia chebula, Terminalia bel- } \\
\text { erica and Syzigium cumini }\end{array}$ & - & $\begin{array}{l}\text { Wheat, Gram } \\
\text { and Mustard }\end{array}$ & Paddy \\
\hline Horti-silvicuture & $\begin{array}{l}\text { Zizyphus maurtiana, Albizzia } \\
\text { lebbeck, Albizzia procera. }\end{array}$ & $\begin{array}{l}\text { Punica granautum, Guava } \\
\text { and mango based orchard }\end{array}$ & & \\
\hline Kitchen garden & $\begin{array}{l}\text { Eucalyptus species, Madhuca } \\
\text { indica and Acacia nilotica }\end{array}$ & $\begin{array}{l}\text { Pomegranate, Annona } \\
\text { reticulate, guava, banana } \\
\text { and Aegle marmelos }\end{array}$ & Radish & $\begin{array}{l}\text { Cabbage, turnip, } \\
\text { radish, carrot, } \\
\text { onion, peas }\end{array}$ \\
\hline Block plantation & $\begin{array}{l}\text { Tectona grandis, Dalbergia } \\
\text { sissoo, Gmelina arborea, } \\
\text { Eucalyptus, Leucaena leuco- } \\
\text { cephala }\end{array}$ & & - & - \\
\hline Silvi-pasture model & $\begin{array}{l}\text { Albizzia lebbeck, Acacia } \\
\text { nilotica, Madhuca indica, Zizy- } \\
\text { phus maurtiana, Tamarindus } \\
\text { indica, Terminalia tomentosa } \\
\text { and Anogeissus latifolia }\end{array}$ & - & $\begin{array}{l}\text { Pasture } \\
\text { Dicanthium an } \\
\text { don dactylon } L\end{array}$ & itum and Cyno- \\
\hline
\end{tabular}


Table 2. Tree preference for various uses.

\begin{tabular}{|c|c|c|c|c|c|c|}
\hline Species & $\begin{array}{l}\text { Method of } \\
\text { planting }\end{array}$ & Fruit & Fodder & Fuelwood & Timber & Soil conservation \\
\hline Terminalia arjuna & N.G & $/$ & - & $\mathrm{X}$ & - & 1 \\
\hline Acacia nilotica & D.S & 0 & / & / & / & / \\
\hline Terminalia tomentosa & N.G & 0 & - & + & - & / \\
\hline Zizyphus maurtiana & D.S & / & / & / & - & $\mathrm{X}$ \\
\hline Butea monosperma & N.G & 0 & $\mathrm{X}$ & / & 0 & / \\
\hline Albizzia lebbeck & D.S & 0 & + & / & / & + \\
\hline Madhuca indica & E.P & / & $\mathrm{X}$ & l & - & $\mathrm{X}$ \\
\hline Terminalia chebula & N.G & / & $\mathrm{X}$ & $\mathrm{X}$ & - & $\mathrm{X}$ \\
\hline Terminalia belerica & N.G & / & - & $\mathrm{X}$ & - & $\mathrm{X}$ \\
\hline Syzigium cumini & D.S and N.G. & / & - & + & - & / \\
\hline Tamarindus indica & E.P & / & $\mathrm{X}$ & - & - & $\mathrm{X}$ \\
\hline Anogeissus latifolia & N.W & 0 & + & / & / & $\mathrm{X}$ \\
\hline Eucalyptus species & E.P & 0 & 0 & + & / & / \\
\hline Tectona grandis & E.P & 0 & 0 & - & / & $\mathrm{X}$ \\
\hline Dalbergia sissoo & D.S and N.G. & 0 & / & / & / & / \\
\hline Gmelina arborea & E.P and D.S. & 0 & / & + & / & + \\
\hline Leucaena leucocephala & D.S & 0 & 1 & / & 0 & / \\
\hline
\end{tabular}

Note: D.S = Direct sowing, E.P = Entire Planting, N.G= Naturally Grown, $/=$ Best, $+=$ Better, $-=$ Good, $X=$ satisfactory, $0=$ No use.

There are many agroforestry practices prevailing in the Dhamtari region. The choice of tree species vary according to the soil, area to area, farmers need, circumstances and socio-economic factors (Choudhary et al., 2012; Hemrom and Nema, 2015). This provides a number of examples of the traditional agroforestry systems and indigenous practices successfully employed by farmers in the district. Traditional agroforestry systems and practices associated with them plays an important role in securing the sustainable livelihood security of the farmers. The tree species provide various output at low cost and are easily accessible; however, utilization pattern varies accroding to seasonalities and from altitudinal ranges (Rawat and Vishvakarma, 2010). A lot of such traditional practices have already been reported which supports the findings of the present investigation (Bhagat et al., 2006; Kanwar and Sharma, 2006; Slathia and Paul, 2012; Choudhary et al., 2012; Hemrom and Nema, 2015). Based on the preference, agroforestry and fruit bearing tree species based system were most preferred system in the study region. Similar finding were also made by Hemrom and Nema (2015) and Choudhary et al. (2012), they reported the most prevalent model in their study area was agri-silviculture and agri-horticulture system, respectively. Based on findings of the present study it was revealed that farmers prefer the species which have multiple output and farmers maintain naturally regenerating tree species, particularly on edges of terraced agriculture fields/bunds without any significant input of manpower. Agri-silvi-pastoral and silvi-pastoral systems are mostly practiced on the marginal and wastelands (Choudhary et al., 2012) which support the present study.

\section{Conclusion}

Most prominent and prevalent models of the study sites were bund based agroforestry and kitchen garden followed by agri-silviculture system, horti-silvicuture, silvi-pasture model and block plantation. But models like orchard and block plantation are least practiced by farmers. Model like agrisilviculture are not well managed in comparison to boundary plantation, orchard and kitchen garden which are well managed and retain by farmers. Whereas, horti-silviculture model is moderatally managed. There is a need to encouraged farmers to adopt these models scientifically and technically for betterment of peoples. Therefore, scientific research and proper extension work is needed in this area before practicing of different agroforestry models and better management practices comprises tending operation should be used properly for a long way in improving the productivity of lands and also in increasing the resources of the area. Similarly, incorporation of research related to different models as per locality factors and their extension will help to make sustainability in different Agroforestry models.

\section{ACKNOWLEDGEMENTS}

Authors are thankful to local respondents for sharing their knowledge with us.

\section{REFERENCES}

Bhagat, G.R., Paul, N. and Slathia, P.S. (2006). Fahadaha: An indigenous dry fodder storage structure of Jammu region. Indian J Tradit. Knowledge, 15(1): 95-96

Choudhary, P., Tandon, V. and Sharma, R. (2012). Traditional agroforestry practices for sustainable livelihood in Rajouri District of Jammu and Kashmir. Journal of Tree Sciences, 31(1-2): 102-107

Das, I.B., Katiyar, P. and Raj, A. (2014). Effects of temperature and relative humidity on ethephon induced gum exudation in acacia nilotica. Asian Journal of Multidisciplinary Studies, 2(10): 114-116

Hemrom, A. and Nema, S. (2015). A study on traditional agroforestry practices existing at Bastar region of 
Chhattisgarh. International Journal of Multidisciplinary Research and Development, 2(3): 56-64

Jhariya, M.K. and Raj, A. (2014). Human welfare from biodiversity. Agrobios Newsletter, 12(9): 89- 91

Jhariya, M.K., Bargali, S.S and Raj, A. (2015). Possibilities and perspectives of agroforestry in Chhattisgarh, Precious Forests - Precious Earth, PP. 237-257 Dr. Miodrag Zlatic (Ed.), ISBN:978-953-51-2175-6, InTech, DOI: 10.5772/60841. Available from: http:// www.intechopen.com/books/precious-forests-preciousearth/possibilities-and-perspectives-of-agroforestry-inchhattisgarh

Jhariya, M.K., Raj, A., Sahu, K.P. and Paikra, P.R. (2013). Neem-a tree for solving global problem. Indian Journal of Applied Research, 3(10): 66-68

Kanwar, P. and Sharma, N. (2006). Tradational storage structures prevalent in Himachali houses. Indian J Tradit. Knowledge, 15(1): 98-103

King, K.F.S. (1969). Agri-silviculture. The taungya system bull. No 7. department of forestry, University of Ibadan, $109 \mathrm{pp}$.

Mughal, A.H. and Bhattacharya, P. (2002). Agroforestry systems practiced in Kashmir valley of Jammu and Kashmir. Indian Forester, pp. 846-852

Mughal, A.H., Tabasum, A. and Bhattacharya, P. (2000). Socioeconomic Aspects of Agroforestry in rural Srinagar of Kashmir Valley. Indian Forester, 126(3): 234-240

Nair, P.K.R. (1989). Agroforestry systems in the tropis. Kluwer Academic Publisher, Dordrecht Netherlands. Pp. 21-38

Painkra, V.K., Jhariya, M.K. and Raj, A. (2015). Assessment of knowledge of medicinal plants and their use in tribal region of Jashpur district of Chhattisgarh, India. Journal of Applied and Natural Science, 7(1): $434-442$

Raj, A., Toppo, P. and Jhariya, M.K. (2016a). Documentation and conservation of medicinal plants in Barnawapara wildlife sanctuary, Chhattisgarh. Van Sangyan, 3 (6): $18-22$

Raj, A., Jhariya, M.K. and Toppo, P. (2016b). Scope and potential of agroforestry in Chhattisgarh state, India. Van Sangyan, 3(2): 12-17

Raj, A. and Jhariya, M.K. (2016). Joint forest management: A program to conserve forest and environment. Van Sangyan, 3(6): 38-42

Raj, A. (2015b). Evaluation of Gummosis Potential Using Various Concentration of Ethephon. M.Sc. Thesis, I.G.K.V., Raipur (C.G.), pp 89
Raj, A. (2015a). Gum exudation in Acacia nilotica: effects of temperature and relative humidity. In Proceedings of the National Expo on Assemblage of Innovative ideas/ work of post graduate agricultural research scholars, Agricultural College and Research Institute, Madurai (Tamil Nadu), pp 151.

Raj, A. (2014). Toxicological effect of Azadirachta Indica. Asian Journal of Multidisciplinary Studies, 2(9): 29-33

Raj, A. and Toppo, P. (2014). Assessment of floral diversity in Dhamtari district of Chhattisgarh. Journal of Plant Development Sciences, 6(4): 631-635

Raj, A., Jhariya, M.K. and Pithoura, F. (2014a). Need of agroforestry and impact on ecosystem. Journal of Plant Development Sciences, 6(4): 577-581

Raj, A., Jhariya, M.K. and Toppo, P. (2014b). Cow dung for ecofriendly and sustainable productive farming. IJSR International Journal of Scientific Research, 3(10): 201202

Rawat, Y. S. and Vishvakarma, S.C.R. (2010). Diversity, distribution and utilization of fodder species in subtemperate, temperate and cold desert region of the Himachal Pradesh, northwestern, Himalaya. Journal of American Science, 6(6): 73-81

Singh, G.B. (1993). Role of Agroforestry in improving the environment. Indian Fmg., 33(3): 15- 19.

Singh, N.R. and Jhariya, M.K. (2016). Agroforestry and agrihorticulture for higher income and resource conservation. Pp. 125-145. In: Innovative Technology For Sustainable Agriculture Development, Edited by Sarju Narain and Sudhir Kumar Rawat (Ed.). ISBN: 978-817622-375-1. Biotech Books, New Delhi, India.

Singh, N.R., Jhariya, M.K. and Raj, A. (2013). Tree crop interaction in agroforestry system. Readers Shelf, 10(3): $15-16$

Slathia, P.S. and Paul, N. (2012) Tradational practices for sutainable livelihood in Kandi belts of Jammu. Indian Journal of Traditional Knowledge, 11(3): 548-552

Toppo, P., Raj, A. and Harshlata. (2014). Biodiversity of woody perennial flora in Badalkhole sanctuary of Jashpur district in Chhattisgarh. J. Env. Bio-Sci., 28 (2): 217-221

Toppo, P., Raj, A. and Jhariya, M.K. (2016). Wild edible plants of Dhamtari district of Chhattisgarh, India. Van Sangyan, 3(4): 1-6

WAC, (2010). Transforming lives and landscapes. World Agro-forestry Centre, United Nations Avenue, Gigiri,Kenya Pp: 1-5 